\title{
Book Reviews - Buchbesprechungen - Livres Nouveaux
}

H. Beckman: Pharmacology. (The Nature, Action and Use of Drugs). W. B. Saunders Company, Philadelphia 1961. 805 pages (illustrated). \$ 15.50 .

This book was written primarily for the medical student who can spend only limited time becoming acquainted with pharmacology. The practicing physician wishing to keep up to date with the recent developments also has a problem. The entire field of pharmacology has been growing so rapidly that it becomes a difficult and challenging task even for a specialist in pharmacology to maintain mastery of the entire subject as it continues to develop at an explosive rate.

Dr. Beckman has written a concise, lucid textbook with excellent bibliographies appended to each chapter. There is a wealth of useful information in this book. The figures used as illustrations are well chosen. There are important summarizing tables, and a liberal use of structural chemical formulas which are very useful to those readers wishing to visualize the differences which exist between the various drug molecules.

Although brevity in this kind of book is important, some sections are too short.

There are some omissions here and there. For example, there is no mention under Antibiotics that erythromycin has on rare occasions caused anaphylaxis.

In Table I, which summarizes the relationship of useful pharmacologic action to predictable undesirable action in a group of 100 commonly used drugs, there is a heading under which the most serious undesirable reactions to drugs are listed. Would it not be realistic to indicate that as one of the most serious direct or indirect adverse reactions, death may sometimes result from various drugs, even when these are used within the so-called therapeutic ranges?

In the discussion of emetic drugs, the author slips in a paragraph which has no place here, on the use of copper sulfate by ophthalmologists in the treatment of trachoma and chronic catarrhal conjunctivitis.

No mention is made in the section on vitamins that large doses of niacinamide can improve joint function.

The author writes that aminopyrine "is capable of causing the full-blown agranu-locytosis picture, however, though admittedly the incidence of even this occurrence is extremely low. Now that penicillin has proved so effective in the handling of such cases when it is used early, the employment of aminopyrine has become a less dangerous thing than formerly, but undoubtedly the hesitancy of the American profession to return to use of the drug in view of the unfortunate occurrences with it a few decades ago is a salutary thing."

But penicillin is not an antidote to aminopyrine-induced agranulocytosis as the author implies. Recovery depends (a) on cessation of aminopyrine treatment, and (b) on the patient's having sufficient reparative power to allow reasonably complete regeneration of bone marrow. Penicillin and other antibiotics, by successfully controlling superimposed infection in aminopyrine-induced agranulocytosis, may be an important factor in keeping the patient alive for that extra margin of time which will allow adequate regeneration of bone marrow - if in the first instance the bone 
marrow was not irreparably damaged by aminopyrine. If it fails to regenerate, the patient dies despite antibiotics and other supportive measures.

Despite the above criticism, I find the book to be a highly useful modern textbook

of pharmacology. It can be read with profit by medical students and practicing physi

cians alike. W. Kaufman, Bridgeport

380 Book Reviews - Buchbesprechungen - Livres Nouveaux

Proceedings of the Seventh Congress of the European Society of Haematology in London, 1959.

Edited by E. Neumark, J. Bernard and G. Discombe. Vol. I: 168 pages; Vol. II/l: 608 pages; Vol. П/2: 681 pages. Illustr. S. Karger, Basel/New York 1960. sFr. 210.-.

Die Verhandlungen des 7. Europäischen Haematologenkongresses liegen nun in drei Bänden vor und bieten auch diesmal eine große Anzahl von Beiträgen, die auch für die Leser der Archives von großer Bedeutung sind. Im ersten Band sind zum Beispiel folgende Beiträge enthalten: A. Cjano: Immuno-morphological findings following the use of hetero-immune sera; M. Seligmann: Anticorps anti-leucocytaires; J. R. Squire: Hypogammaglobulinemia in Great Britain. Im ersten Teil des zweiten Bandes sind 11 Vorträge enthalten, die sich mit immunologischen Problemen beschäftígen und außer-dem 8 Vorträge, welche die Abnormalitäten der Globuline behandeln. Im zweiten Teil des zweiten Bandes werden die Probleme der Blutkoagulation und der Fibrinolyse er-örtert. Danach folgt eine eingehende Besprechung der immunbiologisch wichtigen Probleme der Knochenmarktransplantation in 11 Beiträgen von J. F. Loutit; D. V. Van Bekkum; G. Mathé et al.; H. E. M. Kay et al.; R.Schwartz and J.Donovan; B. G. Crouch; S. Hajdukovic et al.; J. Bohinjec et al.; E. C. Tremblay; G. Giroud und N. Söderström. Im folgenden Teil sind 5 Vorträge über Enzymdefekte in Erythro-zyten, 14 über Haemoglobinopathien und 12 über hämolytische Anaemien enthalten. Blutgruppen und Bluttransfusion wurden in 28 Vorträgen behandelt.

Die ausgezeichnet ausgestatteten Bände geben somit einen guten und vollständigen Überblick über den aktuellen Stand der hämatologischen Forschung und der Klinik der wichtigsten Blutkrankheiten. Paul Kallós, Helsingborg

Kabat, E. A.: Experimental Immunochemistry, Second Edition. Charles C Thomas, Springfield, Illinois, 1961.905 pages. $\$ 26.50$.

The second edition of this classic volume is a superb treatise on experimental immunology. It is beautifully published, carefully and concisely written, richly illustrated with many figures and extended tables of experimental data. Each chapter has an excellent bibliography. The book is a delight to read and to study because of the clarity of presentation and the excellence of style. There are four main sections: Part I deals with immunological and immuno-chemical methodology; Part II with applications of quantitative immunochemical methods; Part III with chemical and physical methods and special procedures used in immunochemistry, and Part IV with Preparations.

Not only are the theoretical aspects of immunochemistry reviewed in an expert manner, but the basis and practice of immunochemistry are described in brilliant detail.

I highly recommend this book as a basic and fundamental textbook of immuno

logy. It should be read by everyone interested in the field of immunology from a re

search or clinical point of view. W. Kaufman, Bridgeport 